bahasa \& sastra, Vol. 14, No.2, Oktober 2014

\title{
PENELITIAN DASAR TERHADAP MOTIVASI MAHASISWA YANG MEMILIH KEAHLIAN PENDIDIKAN BAHASA JEPANG
}

\author{
Natsumi Kobari \\ FPBS Universitas Pendidikan Indonesia \\ Korespondensi: Jl. Dr. Setiabudhi No.229 Bandung 40154 \\ Pos-el:kbrntm@gmail.com
}

\begin{abstract}
Abstrak
Peran dan tanggung jawab Universitas Pendidikan Indonesia (UPI) sangat besar dalam mendidik tenaga pengajar mata pelajaran bahasa Jepang di tingkat SMA/SMK/MA di Indonesia. Oleh karena itu, UPI diharapkan selalu mampu mendidik para tenaga pengajar yang berkualitas. Namun, di sisi lain peneliti berpendapat adanya perbedaan yang besar antara mahasiswa yang berkeinginan belajar bahasa Jepang dan usaha mereka untuk menjadi pengajar bahasa Jepang. Oleh karena itu, Penelitian ini bertujuan untuk mengetahui motivasi para mahasiswa yang memilih keahliannya pendidikan bahasa Jepang dengan menggunakan hasil survei kuesioner terbuka. Dari hasil koding yang diperoleh, diketahui bahwa mayoritas mahasiswa yang termotivasi untuk memilih menjadi mahasiswa yang memiliki keahlian pendidikan bahasa Jepang dipengaruhi oleh ketertarikan mereka terhadap bahasa Jepang. Ketertarikan inilah yang paling banyak dipengaruhi oleh karena adanya hubungan ketertarikan mereka terhadap budaya pop dan pengalaman mereka ketika belajar bahasa Jepang di tingkat SMA/SMK/MA. Selain itu, sebanyak 33\% dari jumlah keseluruhan responden, banyak memilih pekerjaan sebagai pengajar bahasa Jepang di Indonesia, dan jumlah ini lebih sedikit dibandingkan dengan responden yang memiliki alternatif pilihan pekerjaan bukan sebagai pengajar bahasa Jepang. Selain itu, dari hasil penelitian ini diketahui pula, 50\% responden berkeinginan untuk melanjutkan studi lanjut ke jenjang yang lebih tinggi, yakni program S2.
\end{abstract}

Kata-kata kunci: keahlian pendidikan bahasa Jepang, motivasi, pendidikan guru bahasa Jepang

\begin{abstract}
Indonesia University of Education (UPI) takes an important role and responsibility in teachers' training of Japanese language education which is popular at senior high school in Indonesia. UPI is supposed to provide with training regularly to generate qualified Japanese language teachers. Even so, it is seen a significant difference among students in terms of the motivation toward learning Japanese language education and the effort to acquire title for being Japanese language teachers. This research aims to know the motivation of Japanese Education Study Program's students through analysis of the open-ended questionnaire survey result. From the coding result acquired, it was discovered that the majority of the students who were motivated to choose Japanese Education Study Program were influenced by their interest in Japanese language itself, and this interest is affected by the presence of an interest in pop culture and their learning experience in senior high school. In addition, 33\% of all the students are considering becoming a Japanese language teacher as one option, which is less than the ones who are considering finding a job as not Japanese language teacher. Also, more than 50\% of all the students want to continue their study to the higher level, i.e. master degree.
\end{abstract}

Keywords: japanese language teachers, motivation, Japanese language stage 


\section{PENDAHULUAN}

Bahasa Jepang merupakan salah satu mata pelajaran yang dipelajari di tingkat pendidikan menengah ke atas (SMA/MA/SMK) di Indonesia. Para mahasiswa yang memiliki keahlian pendidikan Bahasa Jepang FPBS Universitas Pendidikan Indonesia (UPI) berperan besar dalam memberikan pelatihan dan meluluskan banyak pengajar bahasa Jepang di tingkat sekolah menengah atas di Indonesia. Dengan kata lain, peningkatan kualitas pendidikan bahasa Jepang di UPI terkait dengan terus berkembangnya pendidikan bahasa Jepang di Indonesia.

Departemen Pendidikan Bahasa Jepang UPI menerima mahasiswa unggul kurang lebih 100 orang setiap tahun.Para mahasiswa tersebut adalah mahasiwa yang sebelumnya pernah belajar bahasa Jepang semasa di SMA/SMK/MA, namun ada juga mahasiswa yang belum pernah belajar bahasa Jepang sama sekali. Berdasarkan pengamatan peneliti, ada sedikit perbedaan kemampuan berbahasa Jepang antar mahasiswa baru pada awal perkuliahan dimulai, namun hal tersebut tidak menjadikan adanya perbedaan berarti yang mempengaruhi pembelajaran bahasa Jepang karena semua mahasiswa ditempatkan pada kelas yang sama dan diberikan materi pembelajaran yang sama.

Mahasiswa menempuh studinya selama empat tahun. Mata kuliah yang berhubungan dengan ilmu pendidikan dan pembelajaran bahasa Jepang yang diperoleh mereka di kampus relatif sama, meski tentu saja ada perbedaan cara belajar mandiri pada masing-masing mahasiswa. Akan tetapi, dari prestasi belajar terlihat adanya perbedaan kemampuan berbahasa Jepang yang mencolok begitu mahasiswa menyelesaikan masa studinya walaupun perbedaan kemampuan tersebut tidak terlihat pada saat mereka menuntut ilmu di perguruan tinggi. Selain itu, meskipun UPI adalah perguruan tinggi yang bergerak di bidang pendidikan, bukan berarti mayoritas lulusan UPI adalah lulusan yang ingin menjadi pengajar bahasa Jepang. Di antara para mahasiswa tersebut ada yang sangat berkeinginan untuk menjadi pengajar bahasa Jepang, tetapi ada pulamahasiswayang sama sekali tidak ingin menjadi pengajar bahasa Jepang.

Namun demikian, faktor apa yang mempengaruhi kemampuan berbahasa Jepang dan keinginan mahasiswa untuk menjadi pengajar bahasa Jepang? Hal ini tentu saja dipengaruhi oleh berbagai faktor yang rumit seperti keluarga, lingkungan, bakat terhadap bahasa, karakter, kegemaran, dan lain-lain.Faktor-faktor tersebut bukanlah faktor yang dapat diubah dengan mudah oleh pengajar, terlebih lagi pada masalah yang berhubungan dengan kondisi keluarga. Melihat kondisi seperti ini, dapat dikatakan bahwa usaha yang dapat dilakukan oleh pendidik seolaholahsangatlah terbatas. Akan tetapi, masih ada hal yang dapat dilakukan oleh pengajar yaitu menciptakan motivasi yang memiliki kemungkinan besar untuk memberi pengaruh terhadap kegiatan belajar mahasiswa dan memberikan informasi seputar jalan yang akan mereka pilih setelah selesai kuliah.

Penelitian ini bertujuan untuk mengungkap motivasi mahasiswa UPI yang memilih mahasiswa yang memiliki keahlian pendidikan bahasa Jepang, dan jalan yang akan dipilih mereka begitu selesai kuliah. Di bawah ini adalah dua poin yang menjadi pertanyaan penelitian ("Research Question", selanjutnya akan disingkat menjadi "RQ") pada penelitian ini.

RQ1: Apa yang menjadi motivasi
mahasiswa sehingga mereka
memilih menjadi mahasiswa
yang
keahlianpendidikan memiliki
Jepang?
RQ2: Apa jenis pekerjaan yang ingin
dicapai mahasiswa setelah
menuntut ilmu selama lebih
dari empat semester di
perguruan tinggi?
Pada bidang pendidikan, "motivasi


intrinsik" adalah hal yang penting. "Motivasi intrinsik" adalah sebuah konsep yang digagas oleh Deci (1975) sebagai kebalikan dari "motivasi ekstrinsik". Motivasi intrinsik didasarkan pada penghargaan internal seperti keingintahuan intelektual dari dalam diri sendiri, misalnya pada jawaban siswa yang berbunyi demikian "Karena belajar bahasa Jepang menyenangkan.". Sebaliknya, motivasi ekstrinsik didasarkan pada penghargaan eksternal berupa uang, jabatan, dan lainlain. Contoh motivasi ekstrinsik pada jawaban mahasiswa seperti berikut "Karena saya ingin dipuji oleh guru.".Motivasi intrinsik dan motivasi ekstrinsik pada awalnya dilihat sebagai dua hal yang terpisah, namun pada tahun 1990-an, keduanya dianggap memiliki keterikatan satu sama lain (Ryan \& Deci, 2000, 2002). "Teori determinasi diri” yang memandang dengan menghubungkan antara motivasi intrinsik dan motivasi ekstrinsik ini kemudian banyak diterapkan dalam berbagai penelitian yang berhubungan dengan motivasi.

Penelitian yang berkenaan dengan motivasi pemerolehan bahasa kedua yang menjadi pusat perhatian adalah Gardner \& Lambert (1952, 1972). Dari sudut pandang psikologi sosial, Gardner \& Lambert (1952, 1972) mengklasifikasikan motivasi menjadi dua, yaitu motivasi integratif dan motivasi instrumental. Motivasi integratif adalah motivasi yang mendorong seseorang untuk belajar dengan berpartisipasi dalam lingkungan sosial tempat digunakannya bahasa sasaran serta memahami budaya dan masyarakat penuturnya,. Sebaliknya, Motivasi instrumental adalah motivasi yang mendorong seseorang belajar karena adanya manfaat atau tujuan dari yang dipelajarinya, seperti untuk bekerja atau untuk kenaikan jabatan. Berawal dari Gardner \& Lambert ini, penelitian yang berhubungan dengan motivasi pembelajaran bahasa asing telah banyak dilakukan, dan banyak juga penelitian yang difokuskan pada motivasi pembelajaran bahasa Jepang (Nuibe dkk tahun 1995, Guo dkk tahun 2001, Onishi tahun 2010, dan lain lain).

Meskipun demikian, pada saat ini penelitian mengenai motivasi pengajar bahasa Jepang belum banyak dilakukan. Kalau pun ada penelitian itu jumlahnya masih sedikit, dan masih terfokus pada pengajar bahasa Jepang, yang obyek penelitiannya adalah orang Jepang sebagai penutur asli bahasa Jepang (Kamegawa tahun 2006, dan lain-lain). Penelitian yang mengkaji motivasi pengajar bahasa Jepang dengan orang Indonesia sebagai sasaran penelitiannya, sejauh ini tidak ditemukan sehingga diperlukan penelitian mendasar terlebih dahulu.

\section{METODE PENELITIAN \\ 1. Objek Penelitian}

Objekpenelitian ini adalah mahasiswa tingkat dua yang memiliki keahliannya pendidikan bahasa Jepang di Departemen Pendidikan Bahasa Jepang Universitas Pendidikan Indonesia. Total responden sebanyak 82 orang terdiri atas 20 pria dan 62 wanita yang terbagi dalam tiga kelas. Kuesioner dibagikan kepada 90 orang dengan persentase pengembalian kuesioner sebanyak $91 \%$.

Memasuki tahun 2013 diberlakukan kurikulum baru di Indonesia, yang intinya membebaskan mahasiswa tahun ketiga untuk memilih konsentrasi sesuai dengan keinginannya. Mahasiswa yang memiliki keahlianpendidikan bahasa Jepang direncanakan akan dibagi menjadi dua konsentrasi, yaitu konsetrasi untuk menjadi "pengajar bahasa Jepang" dan konsentrasi "bahasa Jepang untuk bisnis". Adanya konsentrasi "bahasa Jepang untuk bisnis" diharapkan berguna bagi mahasiswa yang akan bekerja di perusahaan-perusahaan Jepang yang notabene cukup populer di kalangan mereka. Selain itu, ada juga kemungkinan terlihatnya fluktuasi jumlah peminat yang berkeinginan menjadi pengajar bahasa Jepang. Untuk itu, mahasiswa perlu diberi motivasi selama dua tahun belajar sejak masuk perguruan tinggi sampai waktunya mereka harus menentukan konsentrasi yang dipilihnya. Hal ini 
diharapkanjuga dapatmemberikan pengaruh baik terhadap masa depan mahasiswa. Atas dasar latar belakang di atas, maka mahasiswa tingkat dua yang dipilih sebagai objek penelitian.

\section{Metode Survei}

Surveidilaksanakan dengan menggunakan lembar kuesioner terbuka yang dibagikan kepada responden pada bulan April tahun 2014. Kuesioner ini dianggap responden sebagai survei yang diadakan setiap empat semester studi yang telah ditempuh mereka. Alasan penggunaan kuesioner terbuka ini bukan dipengaruhi oleh adanya pilihan konsentrasi melainkan agar responden dapat menjawab berdasarkan pemikiran bebas masingmasing responden. Responden tetap diminta menyertakan nama pada lembar kuesioner, dan berkenan bekerjasama dengan baik setelah diberikan penjelasan bahwa jawaban masing-masing yang diisikan pada kuesioner tidak mempengaruhi nilai akademik yang diperoleh pada akhir semester tersebut. Waktu tidak dibatasi dalam mengisi lembar kuesioner sehingga terlihat adanya perbedaan penggunaan waktu yang dibutuhkan untuk menjawab pada tiap responden. Bahasa yang digunakan untuk mengisi lembar kuesioner adalah bahasa Jepang atau bahasa Inggris. Pertanyaan pada lembar kuesioner tercantum di bawah ini :

(1) Mengapa Anda memilih masuk menjadi mahasiswa yang memiliki keahlian pendidikan bahasa Jepang? Apabila alasan tersebut lebih dari satu jawaban, mohon dituliskan semuanya!

(2) Apa harapan Anda setelah lulus kuliah? Apabila jawabannya lebih dari satu, mohon dituliskan semuanya! (Contoh: Ingin melanjutkan ke program S2, Ingin bekerja di perusahaan Jepang yang ada di Indonesia.)

\section{Metode Analisis Data}

Setelah jawaban mahasiswa yang ditulis pada lembar kuesioner dianalisis, dilanjutkan dengan pembuatan koding. Proses koding ditunjukkan sesuai contoh khas pengkodingan data di bawah ini.

\section{Contoh Data :}

高校生以来アニメとマンガが好きです。この時、アニメを見れば、日本の 言葉が分かりませんでした。日本語がきょうみになります。そして日本の 会社で働きたくて、日本へ旅行をしに行きたいです。（原文ママ） (sejak SMA Saya suka anime dan komik Jepang. Saat itu, saya menonton anime,. walaupun saya tidak mengerti bahasa Jepang, Oleh karena itu saya menjadi tertarik pada bahasa Jepang, kemudian saya ingin bekerja di perusahaan Jepang dan berwisata keJepang. ) (data terlampir apa adanya)

Langkah(1) Memberi batasan simpulan arti pada isi uraian dengan menjadikan RQ sebagai sudut pandang pembagian.

高校生以来アニメとマンガが好きです。この時、アニメを見れば、日本 の言葉が分かりませんでした。日本語がきょうみになります。/そして日 本の会社で働きたくて、/日本へ旅行をしに行きたいです。

( Saya sejak SMA suka anime dan komik Jepang. / Saat itu, meskipun saya menonton anime, saya tidak mengerti bahasa Jepang. Oleh karena itu saya jadi tertarik dengan bahasa Jepang, / lalu ingin bekerja di perusahaan Jepang / dan wisata ke Jepang. ) 


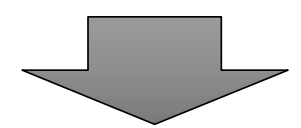

Langkah (2) Membubuhkan kode pada kesimpulan arti.

- Saya sejak SMA suka anime dan komik Jepang. $\Rightarrow$ Anime, Komik

- Saat itu, meskipun saya menonton anime, saya tidak mengerti bahasa Jepang.

Oleh karena itu saya jadi tertarik dengan bahasa Jepang, $\rightarrow$ Bahasa Jepang

$\checkmark$ lalu ingin bekerja di perusahaan Jepang $\Rightarrow$ Perusahaan Jepang

$\diamond$ dan wisata ke Jepang. $\rightarrow$ Wisata ke Jepang

Kode yang terbentuk berdasarkan data ini :

Anime, Komik, Bahasa Jepang, Perusahaan Jepang, Wisata ke Jepang

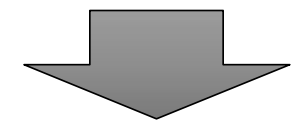

Langkah(3) Membagi semua data dengan proses yang serupa lalu memberi kode.

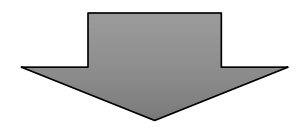

Langkah (4) Meningkatkan level/tingkat ringkasan kodedengan melihat keseluruhan data lalu menyimpulkannya dalam "kategori”.

$\checkmark$ Saya sejak SMA suka anime dan komik Jepang. $\rightarrow$ Anime, Komik

Ketertarikan pada budaya pop

- Saat itu, meskipun saya menonton anime, saya tidak mengerti bahasa Jepang.

Oleh karena itu saya jadi tertarik dengan bahasa Jepang, $\rightarrow$ Bahasa Jepang

$\rightarrow$ Ketertarikan pada bahasa Jepang

lalu ingin bekerja di perusahaan Jepang $\Rightarrow$ Perusahaan Jepang $\Rightarrow$ Pekerjaan

(Selain Guru Bahasa Jepang)

$\diamond$ dan wisata ke Jepang. $\quad \Rightarrow$ Wisata ke Jepang $\rightarrow$ Ketertarikan pada Jepang

Kategori yang terbentuk berdasarkan data ini :

Ketertarikan pada Budaya Pop, Ketertarikan pada Bahasa Jepang, Pekerjaan (Selain Guru Bahasa Jepang), Ketertarikan pada Jepang”,

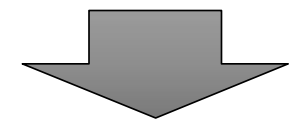

Langkah (5) Membuat tabel dan grafik dengan menghitung persentasi dan jumlah responden dalam setiap kategori. 


\section{HASIL DAN PEMBAHASAN}

Pada bab ini dibahas hasil dan pembahasan analisis. Kategori ditunjukkan dengan simbol kurung siku [ ], kode ditunjukkan dengan simbol kurung sudut $<>$, dan simbol dengan tanda arsetik " " akan digunakan untuk menunjukkan kutipan atau penekanan. Sebagai catatan, isi dari jawaban responden akan diperlihatkan secara keseluruhan dan akan dilengkapi terjemahan dalam bahasa Indonesia.
1. Motivasi Mahasiswa yang Memilih Keahlianya Pendidikan Bahasa Jepang

Tabel 1 menunjukkan 13 kategori motivasi mahasiswa yang memilih sebagai mahasiswa yang memiliki keahlian pendidikan bahasa Jepang yang diperoleh dari hasil koding dari lembar kuesioner terbuka terhadap pertanyaan nomor 1 . Perlu dijelaskan bahwa jumlah responden pada tabel tidak sama dengan jumlah jawaban responden karena ditemukan jawaban responden yang lebih dari satu buah.

\section{Tabel 1. Daftar Kategori yang Terbentuk dan Kode yang Termasuk di dalamnya}

\begin{tabular}{|c|c|c|c|}
\hline & Kategori & Kode yang termasuk dalam kategori & (orang) \\
\hline 1 & $\begin{array}{l}\text { Ketertarikan responden pada } \\
\text { bahasa Jepang }\end{array}$ & Bahasa Jepang / Huruf / Percakapan / Pengucapan & 40 \\
\hline 2 & $\begin{array}{l}\text { Ketertarikan responden pada } \\
\text { budaya pop }\end{array}$ & $\begin{array}{l}\text { Anime / Musik / Permainan / Komik / Drama / Film } \\
\text { / Karakter Anime }\end{array}$ & 22 \\
\hline 3 & $\begin{array}{r}\text { Akibat pengaruh pengalaman } \\
\text { belajar bahasa Jepang di SMA }\end{array}$ & Mata pelajaran di SMA & 22 \\
\hline 4 & $\begin{array}{l}\text { Tidak ada hubungan dengan } \\
\text { Jepang }\end{array}$ & $\begin{array}{l}\text { Gagal lulus ujian masuk perguruan tinggi yang } \\
\text { mereka inginkan//Beasiswa/Tidak ada Departemen } \\
\text { yang diinginkan/Tingkat ketenaran } \\
\text { universitas/Melanjutkan studi ke universitas/Tidak } \\
\text { suka matematika }\end{array}$ & 18 \\
\hline 5 & $\begin{array}{l}\text { Ketertarikan responden pada } \\
\text { Jepang }\end{array}$ & $\begin{array}{l}\text { Kunjungan ke Jepang / Suka Jepang /Pemahaman } \\
\text { terhadap Jepang/Wisata ke Jepang/Berhubungan } \\
\text { dengan orang Jepang }\end{array}$ & 17 \\
\hline 6 & $\begin{array}{c}\text { Pekerjaan } \\
\text { (pengajar bahasa Jepang) }\end{array}$ & Pengajar bahasa Jepang & 17 \\
\hline 7 & Pengaruh orang sekitar & $\begin{array}{l}\text { Rekomendasi keluarga/Pengaruh } \\
\text { keluarga/Keinginan orangtua/Rekomendasi guru } \\
\text { SMA/Pengaruh teman/Rekomendasi teman }\end{array}$ & 17 \\
\hline 8 & $\begin{array}{c}\text { Pekerjaan } \\
\text { (Selain guru bahasa Jepang) }\end{array}$ & $\begin{array}{l}\text { Bekerja di Jepang / Perusahaan Jepang di } \\
\text { Indonesia/Nilai tambah dalam mencari } \\
\text { pekerjaan/Pegawai kedutaan di Jepang/Pemandu } \\
\text { turis/Penerjemah }\end{array}$ & 11 \\
\hline 9 & $\begin{array}{l}\text { Ketertarikan responden pada } \\
\text { keseluruhan budaya Jepang }\end{array}$ & Budaya Jepang & 9 \\
\hline 10 & $\begin{array}{l}\text { Ketertarikan responden pada } \\
\text { bahasa Asing }\end{array}$ & Bahasa Asing & 4 \\
\hline 11 & $\begin{array}{l}\text { Ketertarikan responden pada } \\
\text { sejarah dan sastra Jepang }\end{array}$ & Sejarah/Sastra & 1 \\
\hline 12 & $\begin{array}{l}\text { Ketertarikan responden pada } \\
\text { teknologi Jepang }\end{array}$ & Teknologi & 1 \\
\hline 13 & Lainnya & Agama/Hubungan Jepang dan Indonesia & 2 \\
\hline
\end{tabular}




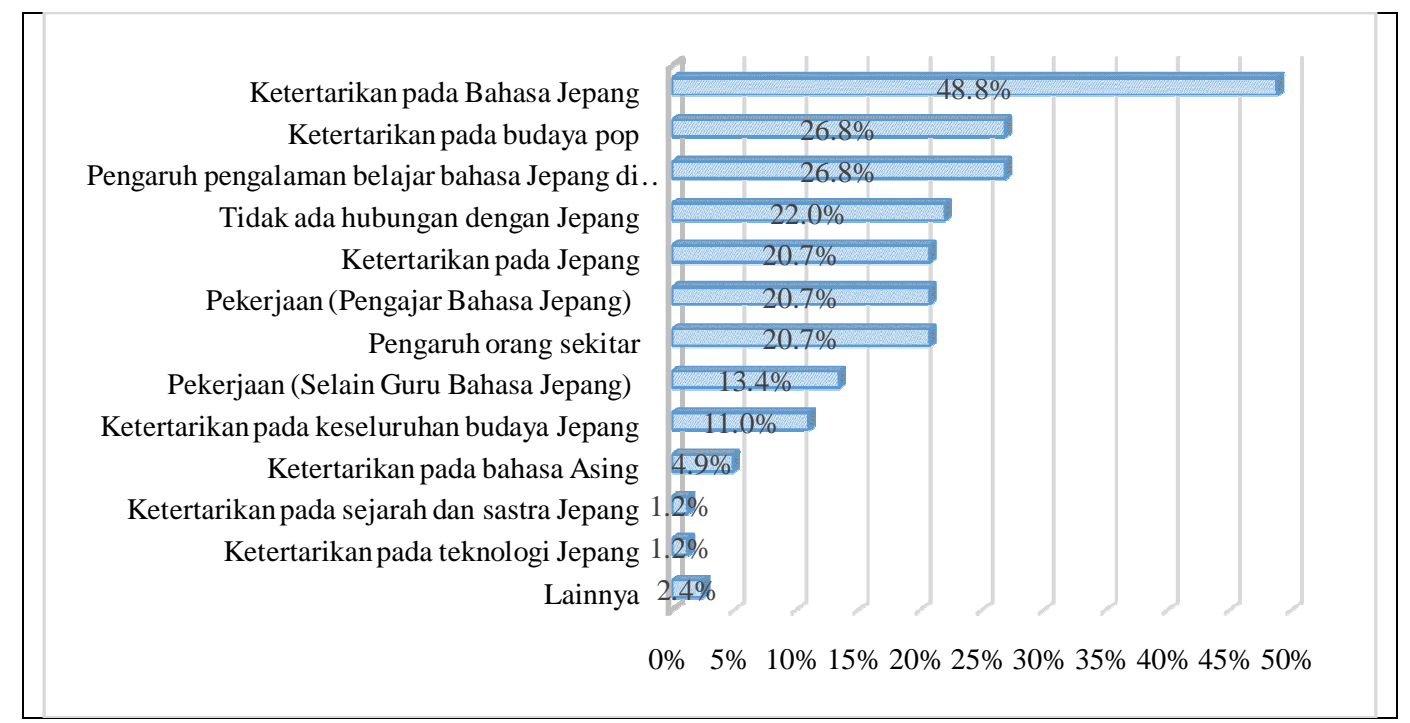

\section{Grafik 1. Motivasi Mahasiswa yang Memilih Keahliannya Pendidikan Bahasa Jepang}

Seperti yang ditunjukkan pada grafik di atas, dapat diketahui bahwa mahasiswa yang memilih keahliannya pendidikan bahasa Jepang termotivasi oleh adanya [Ketertarikan pada bahasa Jepang], dan jawaban ini adalah jawaban terbanyak yang mendekati hampir setengah dari jumlah responden. Akan tetapi, ada faktor kuat lainnya yang mempengaruhi motivasi mahasiswa meski tidak mencapai $30 \%$.

$$
\text { Yang dimaksud dengan }
$$

[Ketertarikan pada bahasa Jepang] adalah adanya ketertarikan terhadap bahasa Jepang sebagai sebuah bahasa dan semua hal yang menyertainya. Selain jawaban "Bahasa Jepang menyenangkan." dan "Saya suka bahasa Jepang.", muncul juga jawaban lain seperti "Hurufnya unik." dan "Pelafalan bahasa Jepang unik.".

UPI adalah perguruan tinggi yang bergerak di bidang pendidikan sehingga mahasiswa yang memiliki keahlian yang ada bukanlah mahasiswa yang memiliki keahlian bahasa Jepang melainkan mahasiswa yang memiliki keahlian pendidikan bahasa Jepang. Akan tetapi, ketika mereka memasukibidang keahlian ini, ada kencenderungan bahwa mereka lebih mengutamakan ketertarikan terhadap "bahasa Jepang" daripada "pendidikan" itu sendiri.

[Ketertarikan terhadap bahasa Jepang] yang menjadi faktor terbesar ini bukan berarti sebagai faktor yang berdiri sendiri namun hingga kini belum diketahui adanya hubungan pengaruh dengan faktor yang lain. Misalnya, dari jawaban di bawah ini dapat diketahui bahwa [Ketertarikan terhadap budaya pop] mendapat pengaruh dari [Ketertarikan terhadap bahasa Jepang].

「私は高校生の時、日本語科目はないのに、アニメから受けて日本語が好きに なりました。」(Ketika saya belajar di SMA, di sekolah saya tidak ada mata pelajaran bahasa Jepang tapi saya menyukai bahasa Jepang akibat pengaruh anime.)

•「日本語が上手になりたいです。日本のアニメが好きですから。」(Saya ingin pandai berbahasa Jepang karena saya suka Anime Jepang.)

- "Because, when I was junior high school, I always watched anime. And my favorit anime is Detective Conan and hunter $X$ hunter, that was first time why I love Japanese and want to learn Japanese."(Karena semasa SMP saya selalu menonton Anime. Anime kesukaan saya adalah 'Detective Conan' dan 'Hunter X Hunter'; itu adalah pertama kalinya saya menyukai bahasa Jepang dan ingin mempelajarinya.) 
Budaya pop seperti anime dan komik tidak dapat diabaikan sebagai hiburan pribadi. Kementerian Luar Negeri Jepang juga mengembangkan budaya pop menjadi "diplomasi budaya pop" yang digunakan sebagai "alat utama diplomasi budaya" dalam rangka "mempromosikan kepercayaan dan pemahaman yang lebih" tentang Jepang. Budaya pop diakui sebagai salah satu kata kunci penting pada bidang pendidikan bahasa Jepang beberapa tahun terakhir. Telah banyak diadakan praktik pendidikan (Yazaki tahun 2012, Suzuki tahun 2014, dan lain-lain) dan pengembangan bahan ajar (The Japan Foundation tahun 2010, dan lain-lain) yang menggunakan budaya pop.

Dari hasil survei yang menyatakan bahwa budaya pop juga menjadi alasan para mahasiswa masuki bidang keahlian pendidikan bahasa Jepang di UPI, dapat juga dikatakan bahwa ada kemungkinan keterkaitan antara praktik pendidikan yang menggunakan media budaya pop di UPI dengan peningkatan motivasi dan pemerolehan bahasa Jepang pada mahasiswa. Di sisi lain, pada kenyataannya ada juga kelompok mahasiswa yang sama sekali tidak tertarik pada budaya pop, kebalikan dengan kelompok mahasiswa yang memiliki ketertarikan khusus terhadap budaya pop, yang dapat juga disebut sebagai "otaku". Oleh karena itu, tidak dapat dinyatakan begitu saja bahwa praktik pendidikan yang menggunakan media budaya pop sangat efektif bagi semua mahasiswa. Oleh karenanya, budaya popdiharapkan hanya digunakan pada aktivitas di luar kelas, bukan pada pembelajaran utama di dalam kelas.

Peran pengajar pada situasi seperti ini yaitu memperkenalkan bahan ajar yang berkaitan dengan budaya pop pada mahasiswa dan membantu mereka mengembangkan cara belajar dengan memanfaaatkan budaya pop. Dengan kata lain, dapat dikatakan bahwa peran penting pengajar di sini adalah dapat terus memberikan dukungan supaya mahasiswa yang tertarik pada budaya pop tetap dapat belajar sambil menikmati "belajar mandiri" menggunakan anime atau komik dengan usahanya sendiri.

Pengaruh terhadap [Ketertarikan pada bahasa Jepang] bukan hanya dari [Ketertarikan pada budaya pop] saja. Hal ini juga dipengaruhi oleh [Pengaruh pengalaman belajar bahasa Jepang di SMA] yang dapat dilihat dari jawaban responden di bawah ini.

「高校で日本語の先生は日本語で話した時、とても私は日本語を話せたいです

。」(Ketika guru bahasa Jepang di SMA berbicara bahasa Jepang, saya juga ingin bisa berbicara bahasa Jepang.)

•「高校の時日本語をべんきょうしたことがあります。それで日本語がどんどん 好きです。」(Saya pernah belajar bahasa Jepang di SMA. Oleh karena itu perlahanlahan saya menyukai bahasa Jepang.)

•「高校の時、三年生に何がっか、大学にも何を入りたいのをまだ知りませんの で、この時、日本語が一番好きなじゅぎょうだと思うので、日本語がっかをき めます。」(Ketika kelas 12 SMA,saya belum tahu bidang keahlian apa yang akan saya masuki di perguruan tinggi, tetapi karena ketika itu saya paling suka mata pelajaran bahasa Jepang sehingga saya memutuskan untuk masuki Departemen bahasa Jepang.)

Berdasarkan survei yang dilakukan oleh The Japan Foundation pada tahun 2013 terdapat pembelajar bahasa Jepang di Indonesia sebanyak 872.411 siswa. Angka ini merupakan angka terbesar kedua di dunia setelah Cina. Di antara 872.411 siswa tersebut, sebanyak 835.938 orang diantaranya berada pada tingkat menengah ke atas, yaitu siswa SMA. Pada saat ini, jumlah di atas tidak dapat dipastikan akan 
bertahan atau justru berkurang sebagai dampak diberlakukannya kurikulum baru yaitu kurikulum 2013 di Indonesia. Akan tetapi, setelah diperoleh bahwa adanya [pengaruh pengalaman belajar bahasa Jepang di SMA] yang ditulis secara eksplisit oleh $27 \%$ responden pada penelitian ini, maka dapat disimpulkan bahwa pendidikan bahasa Jepang di SMA sedikit banyak mempengaruhi keputusan siswa dalam menentukan pilihannya untuk studi lanjut ke perguruan tinggi dan menentukan jalan hidup mereka di masa yang akan datang.

Yang menjadi pertanyaan berikutnya adalah apa yang mempengaruhi pendidikan bahasa Jepang pada tingkat SMA? Mengingat bahwa lulusan UPI sebagian besar aktif sebagai guru bahasa Jepang di SMA-SMA di Jawa Barat, tidak diragukan lagi bahwa kualitas pendidikan bahasa Jepang di UPI adalah salah satu pengaruhnya. Usaha peningkatan kualitas baik pengajar bahasa Jepang di UPI terkait dengan peningkatan kualitas pendidikan bahasa Jepang di tingkat SMA sehingga mahasiswa memilih keahlian pendidikan bahasa Jepang di UPI setelah mengenyam pendidikan bahasa Jepang yang berkualitas semasa SMA dan mengetahui betapa menariknya bahasa Jepang. Kemudian, mahasiswa unggul yang menuntut ilmu pendidikan bahasa Jepang di UPI akan menjadi guru bahasa Jepang di SMA begitu mereka lulus. (gambar 1). Menyadari adanya fakta "pendidikan bersiklus" seperti ini, tidak perlu dijelaskan panjang lebar lagi bahwa penanganan setiap hari sangat diperlukan dan tidak ada yang dinamakan usaha yang sia-sia untuk meningkatkan kualitas pendidikan.

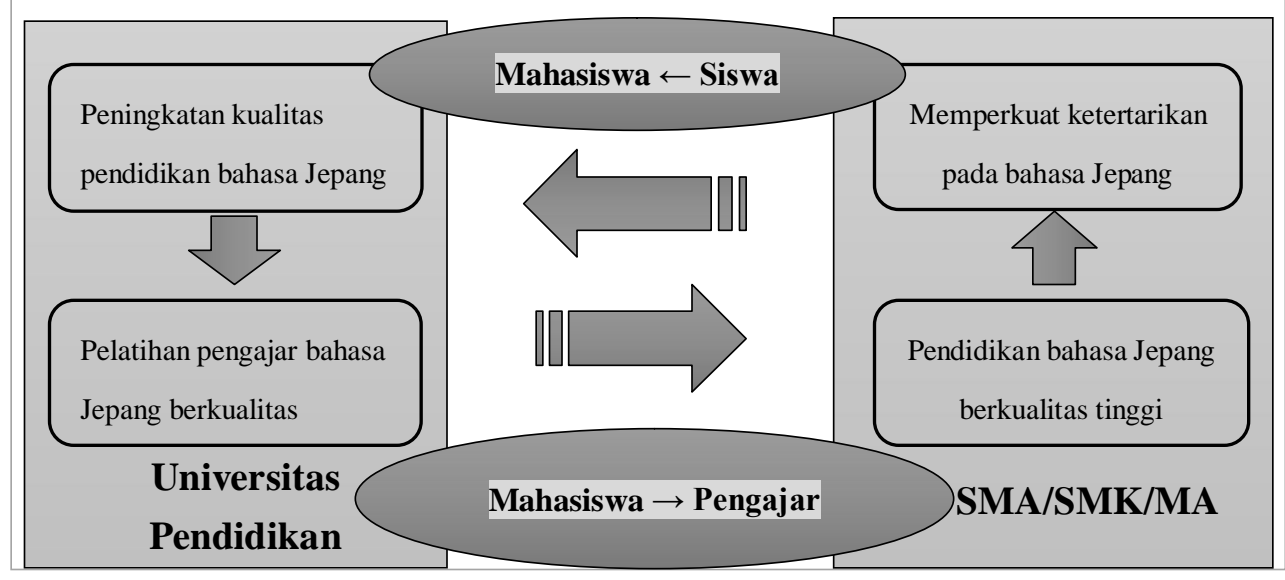

Gambar 1. Siklus Pendidikan Bahasa Jepang

Kebalikan dari ketertarikan terhadap bahasa atau budaya Jepang yang telah dipaparkan di atas, diperoleh juga jawaban responden sebanyak $22 \%$ yang menyatakan bahwa faktor [Tidak ada hubungan dengan Jepang] sebagai alasan menjadi mahasiswa yang memiliki keahlian bahasa Jepang.
Misalnya seperti yang tersebut berikut ini : $<$ tidak lulus ujian masuk perguruan tinggi>, $<$ beasiswa $>$, <tidak ada program studi yang diinginkan>, <tingkat ketenaran universitas $>$, <melanjutkan sekolah>, <tidak suka matematika>, dan lain-lain.

「英語学科をえらびました。でもしけんの時しつぱいしました。」(Awalnya Saya memilih program studi bahasa Inggris tetapi saya tidak lolos ujian masuknya.)

"At the first, I was looking for mandarin, but instead theres only Japanese here. I thought "It's okay.Japanese and Mandarin is almost same though." so here I am."(Awalnya, saya mencari bahasa Mandarin, tetapi hanya ada bahasa Jepang di 
sini. "Tak apalah, saya pikir karena bahasa Jepang dan Mandarin khan hampir sama.". Oleh karena itu, saya sekarang di sini.)

•「実は、はじめて日本語がっかに入る時、きょうみがありません。日本語がっ かに入るは、ただラッキーです。UPIはゆうめいな大学ですから、UPIに入りま す。そして私はすうがくがきらいです。」(Sebenarnya, ketika pertama kali saya memasuki program studi Pendidikan Bahasa Jepang, saya tidak berminat terhadap bahasa Jepang. Saya masuk ke program studi ini hanya keberuntungan saja. Saya masuk UPI karena UPI merupakan universitas ternama. Selain itu, saya juga tidak suka matematika.)

Selain itu, sebanyak 20,7\% responden teman>, dan <rekomendasi teman>. menyatakan adanya [pengaruh orang Berkenaan dengan hubungan interpersonal sekitar] yang dinyatakan dengan jawaban seperti ini, hasil yang sama juga diperoleh <rekomendasi keluarga>, <pengaruh Imuta (2009) pada penelitiannya terhadap keluarga>, <keinginan orangtua>, motivasi mahasiswa calon pengajar bahasa $<$ rekomendasi guru SMA>, <pengaruh Jepang di Thailand.

•日本語でしょうらいがひろいですから、りょうしんがすすめるから。」(Orang tua saya merekomendasikannya. Menurut mereka, bahasa Jepang dapat memperluas masa depan saya.)

- "My parents want me to be a teacher, and study in Java. Because UPI is near from Lampung. If I study in Jogja, is so far to me."(Orang tua saya ingin saya menjadi guru dan belajar di pulau Jawa. Karena UPI dekat dari Lampung. Jika saya belajar di Jogja, itu dirasa terlalu jauh.)

- "Because my father had been worked in Japan, so he want to see his daughter go to Japan." (Karena ayah saya pernah bekerja di Jepang, jadi beliau ingin melihat anaknya pergi ke Jepang juga.)

Dari alasan [Tidak ada hubungan dengan Jepang] ini, dapat diketahui bahwa ada juga mahasiswa yang masuki program studi Pendidikan Bahasa Jepang bukan atas keinginan diri sendiri, melainkan karena adanya [pengaruh orang sekitar]. Mahasiswa yang seperti itu perlu diberi materi pendidikan yang dapat membuat dirinya mencari tahu maksud dari pemilihan Departemen Pendidikan Bahasa Jepang. Terlepas nantinya para lulusan akan menjadi guru bahasa Jepang atau tidak, Hal ini merupakan tanggungjawab perguruan tinggiuntuk terus mendukung mahasiswa agar dapat terjun dalam bidang yang sesuai dengan bakat yang dimilikinya.

\section{Harapan Setelah Lulus Kuliah}

Tabel 2 menunjukkan 7 kategori "harapan mahasiswa setelah lulus kuliah" yang diperoleh dari hasil koding dari lembar kuesioner terbuka terhadap pertanyaan nomor 2. Sebagai catatan, jumlah responden pada tabel tidak sama dengan jumlah responden karena diakui adanya jenis jawaban lebih dari satu dari masing-masing responden. 
Tabel2. Daftar Kategori yang Terbentuk dan Kode yang Termasuk Di dalamnya

\begin{tabular}{lclc}
\hline & Kategori & \multicolumn{1}{c}{ Kodeyang termasuk dalam kategori } & (orang) \\
\hline $\mathbf{1}$ & $\begin{array}{c}\text { Pekerjaan di Indonesia } \\
\text { (Selain Pengajar Bahasa Jepang) }\end{array}$ & $\begin{array}{l}\text { Pengajar (Selain bahasa Jepang) / Perusahaan Jepang di } \\
\text { Indonesia / Penerjemah tulisan / Pemandu turis / } \\
\text { Penerjemah lisan / Penulis Komik / Novelis bahasa } \\
\text { Jepang / Polisi Internasional / Pramugari }\end{array}$ & 51 \\
\hline $\mathbf{2}$ & Melanjutkan ke program S2 & $\begin{array}{l}\text { S2 di Jepang / S2 di Indonesia / S2 di Inggris / S2 di } \\
\text { Korea }\end{array}$ & 46 \\
\hline $\mathbf{3}$ & $\begin{array}{c}\text { Pekerjaan di Indonesia } \\
\text { (Pengajar Bahasa Jepang) }\end{array}$ & Pengajar Bahasa Jepang & 27 \\
\hline $\mathbf{4}$ & Pekerjaan di Jepang & Pekerjaan di Jepang & 25 \\
\hline $\mathbf{5}$ & Wirausahawan & $\begin{array}{l}\text { Les Privat / Sekolah / Toko Buku / Kedai Kopi / } \\
\text { Restauran }\end{array}$ & 6 \\
\hline $\mathbf{6}$ & Sekolah di Jepang (Selain S2) & Sekolah (Permainan ) / Sekolah (Sepak Bola) & 2 \\
\hline $\mathbf{7}$ & Belum ada tujuan pasti & Masih belum tahu mau apa & 2 \\
\hline
\end{tabular}

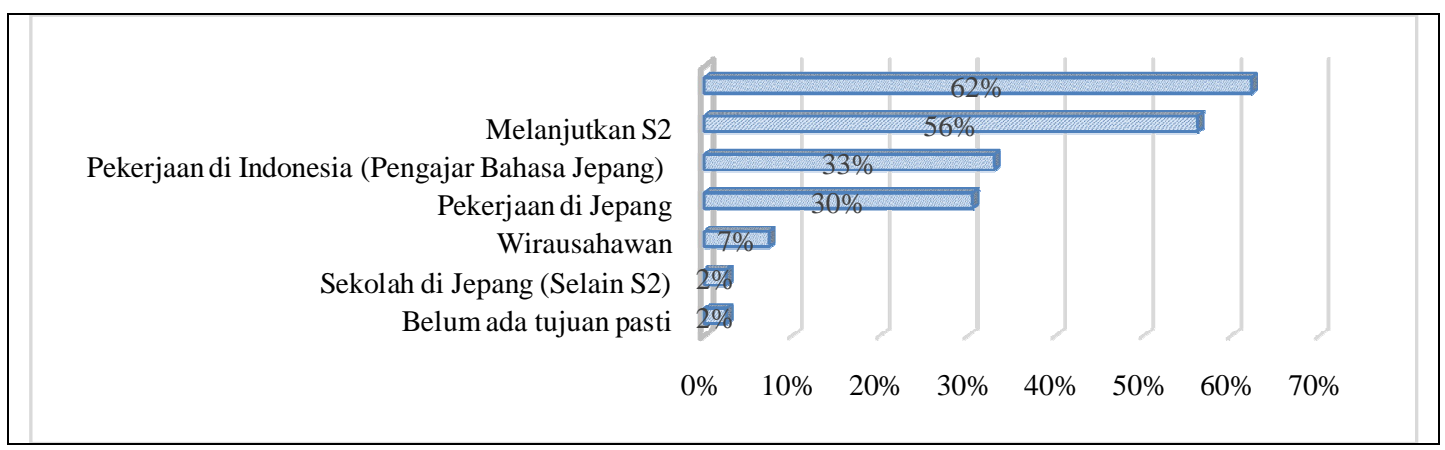

\section{Grafik 2. Harapan Setelah Lulus Kuliah}

Sebanyak $62 \%$ responden memilih [Pekerjaan di Indonesia (selain pengajar bahasa Jepang)] sebagai harapan setelah lulus kuliah, dan ini merupakan jawaban terbanyak. Pilihan terbanyak mengarah pada pekerjaan di <perusahaan Jepang di Indonesia>. Sebagai fakta bahwa baiknya kualitas perlakuan terhadap pegawai di <perusahaan Jepang di Indonesia> sudah diketahui oleh banyak orang. Selain itu, responden yang menginginkan <pekerjaan di Jepang >sebanyak 30\%, dan yang ingin menjadi <wirausahawan>sebanyak $7 \%$. Setelah mempertimbangkan jawaban responden yang memilih [pekerjaan (selain pengajar bahasa Jepang) hanya $13,4 \%$ pada bagian "motivasi memilih Mahasiswa yang memiliki keahlian pendidikan bahasa Jepang" sebelumnya, dapat diketahui bahwa setelah mereka menuntut ilmu selama kurang lebih dua tahun, mahasiswa mulai menyadari adanya pilihan karir selain menjadi pengajar bahasa Jepang.

Di sisi lain, diketahui pula bahwa terdapat responden yang memilih [Pekerjaan di Indonesia (Pengajar Bahasa Jepang)] sebanyak 33\%, dan angka ini lebih rendah dibandingkan yang memilih [Pekerjaan di Indonesia (Selain Pengajar Bahasa Jepang)]. Seperti yang ditunjukkan oleh Grafik 1 pada bagian terdahulu, responden yang memilih [Pekerjaan (Pengajar Bahasa Jepang)] sebagai motivasi memilih Mahasiswa yang memiliki keahlian pendidikan bahasa Jepang ada sebanyak 17 orang, atau sebanyak 20,7\%. 17 responden tersebut juga memilih pilihan yang sama, yaitu [Pekerjaan di Indonesia(Pengajar Bahasa Jepang)] pada pertanyaan 2. Oleh karena itu, tidak ada mahasiswa yang "kehilangan minatnya untuk menjadi pengajar bahasa Jepang setelah belajar kurang lebih dua tahun, 
meskipun tujuan awal masuk ke perguruan tinggi adalah untuk menjadi pengajar bahasa Jepang”. Ini merupakan info kunci bagi Mahasiswa yang memiliki keahlian yang mengadakan pelatihan pengajar bahasa Jepang. Dengan mengadakan penelitian kualitatif terhadap langkah-langkah untuk mempertahankan motivasi pada 17 orang tersebut, tentu hasilnya akan berguna bagi praktik pendidikan untuk mahasiswa generasi berikutnya yang juga bertujuan menjadi pengajar bahasa Jepang.

Hal penting yang harus diperhatikan oleh mahasiswa yang memiliki keahlian pendidikan bahasa Jepang adalah 10 orang mahasiswa yang "ingin menjadi pengajar bahasa Jepang setelah belajar kurang lebih dua tahun meski awalnya tidak ada minat sama sekali untuk menjadi pengajar bahasa Jepang." Jika diadakan penelitian lebih lanjut mengenai motivasi keinginan menjadi pengajar bahasa Jepang pada 10 mahasiswa ini, ada kemungkinan dapat memberi pengaruh baik pada generasi mahasiswa berikutnya untuk dimotivasi menjadi pengajar bahasa Jepang meski pada awal masuk kuliah mereka sama sekali tidak memiliki minat untuk itu.

Selain itu, seperti yang ditunjukkan sebelumnya, diketahui bahwa lebih dari setengah jumlah responden yaitu $56 \%$ memilih [melanjutkan S2], dengan perincian $<$ S2 di Jepang $>$ sebanyak 25 orang, $<$ S2 di Indonesia $>$ sebanyak 19 orang, $<\mathrm{S} 2$ di Inggris $>$ sebanyak 1 orang, dan $<\mathrm{S} 2 \mathrm{di}$ Korea $>$ sebanyak 1 orang. Dari sudut pandang "sekolah di Jepang", setelah ditambahkan dengan dua responden yang memilih [Sekolah di Jepang (selain S2)] untuk mendalami sepakbola atau game, maka didapatkan hasil bahwa 27 orang, atau $33 \%$ dari total responden mempertimbangkan untuk melanjutkan studi di Jepang setelah mereka lulus kuliah. Dilihat dari ketiadaan jawaban mengenai tujuan untuk "sekolah di Jepang pada pada bagian "motivasi memilih Mahasiswa yang memiliki keahlian pendidikan bahasa Jepang" sebelumnya, dapat dikatakan bahwa mahasiswa menyadari adanya opsi melanjutkan studi di Jepang begitu mereka lulus kuliah nanti.

Ada juga mahasiswa yang memilih kondisi "jika memperoleh beasiswa" pada pilihan tersebut, namun banyak beasiswa yang mensyaratkan pelamar untuk memiliki sertifikat kemampuan berbahasa Jepang pada tingkat tertentu. Selain itu, diperlukan adanya pemahaman mengenai penggunaan bahasa Jepang akademik jika ingin melanjutkan kuliah ke jenjang pascasarjana (Program S2) bidang humaniora di Jepang. Banyak juga mahasiswa program S2 yang dapat mengambil kelas internasional yang disampaikan dalam bahasa Inggris, namun jika melihat kondisi mereka ini, pilihan studi yang akan diambil nanti tentunya adalah bahasa atau budaya Jepang. Oleh karena itu, dapat diperkirakan bahwa mereka harus mencapai kemampuan bahasa Jepang pada tingkat yang tinggi.

「大学から卒業したら、日本の大学院生で日本語を勉強したいんです。」(Setel ah lulus S1, saya ingin belajar di program S2 bahasa Jepang di Jepang.)

•「日本のだいがくいんへ入りたいです。日本のぶんかをべんきょうしたいです -」(Saya ingin masuk program S2 di Jepang. Saya ingin belajar budaya Jepang.)

•「日本で修士、文学をつづけたいです。」(Saya ingin melanjutkan studi ke program S2 sastra di Jepang.)

Bukanlah hal yang mudah bagi mahasiswa untuk dapat mencapai tingkat kemampuan berbahasa Jepang yang cukup untuk melanjutkan studi di Jepang hanya dalam empat tahun studi di perguruan tinggi meskipun tetap ada perbedaan antara satu mahasiswa dengan lainnya. Maka dari itu, mahasiswa yang ingin melanjutkan studi di Jepang perlu menyadari sejak dini pentingnya kemampuan berbahasa Jepang 
pada tingkat tinggi dan melanjutkan pembelajaran bahasa Jepang secara mandiri untuk mendukung keinginan tersebut. Jika kampus dapat memberikan materi-materi penting untuk melanjutkan studi di Jepang secara detil dengan mengadakan kuliah khusus seperti "Kelas Persiapan Masuk Program S2 di Jepang" yang kemudian dapat mengarahkan mahasiswa pada belajar mandiri, hal ini sedikit banyak akan membantu mereka. Dengan satu tujuan yaitu meningkatkan kemampuan berbahasa Jepang seluruh mahasiswa, pengajar harus mampu mengambil tindakan agar mahasiswa dapat mencapai tujuannya walaupun itu hanya satu orang mahasiswa saja.

\section{SIMPULAN}

Penelitian ini telah mengungkap motivasi mahasiswa yang memilih menjadi mahasiswa yang memiliki keahlian pendidikan bahasa Jepang dan jalan yang akan mereka tempuhapabila selesai kuliahnya nanti. Penelitain ini diperoleh dari surveiyang menggunakan kuesioner terbuka yang respondennya sebanyak 82 orang. Tentu saja, memilih responden yang memiliki keahlian pendidikan bahasa Jepang bukan berarti mengharuskan semua mahasiswa untuk menjadi pengajar bahasa Jepang. Pilihan kerja mereka, tentunya ditentukan oleh keinginan masing-masing. Pada kenyataannya, tidak ada jaminan bahwa semua mahasiswa akan segera mendapat jabatan sebagai pengajar bahasa Jepang begitu mereka lulus, namun bagi mahasiswa yang memiliki keahlian pendidikan bahasa Jepang tetap harus dapat termotivasi apalagi mereka adalah mahasiswa UPI yang nota bene merupakan universitas yang bergerak di bidang pendidikan, sudah sewajarnya mampu mencetak pengajar-pengajar bahasa Jepang yang berkualitas baik. Perlu adanya kesadaran diri dari tiap dosen untuk menyampaikan pesona dari profesi pengajar bahasa Jepang dengan memotivasi mahasiswa pada peningkatan kemampuan berbahasa Jepang dan minat pada pendidikan bahasa Jepang dalam interaksi sehari hari di dalam kelas.

Penelitian ini adalah penelitian mendasar yang mengkaji motivasi mahasiswa yang memilih keahlian pendidikan bahasa Jepang dan jalur yang diinginkan oleh mahasiswa setelah lulus nanti. Penelitian ini bertujuan untuk pengembangan pengkajian lebih lanjut seperti tersebut di bawah ini.

1. Penelitian kualitatif terhadap mahasiswa yang memilih ingin memiliki keahlian pendidikan bahasa Jepang karena ingin menjadi pengajar bahasa Jepang sejak awal masuk untuk mengungkap bagaimana mahasiswa mempertahankan motivasinya tersebut.

2. Penelitian kualitatif terhadap mahasiswa berkeinginan menjadi pengajar bahasa Jepang muncul setelah memasuki perguruan tinggi untuk mengungkap perubahan motivasi mereka.

3. Penelitian kuantitatif atau kualitatif terhadap mahasiswa yang memiliki tujuan bekerja bukan sebagai pengajar bahasa Jepang dan penelitian analisis perbandingan dengan motivasi mahasiswa yang berkeinginan menjadi pengajar bahasa Jepang.

\section{UCAPAN TERIMA KASIH}

Peneliti mengucapkan terima kasih banyak kepada semua pihak yang terlibat dalam penelitian ini, terutama kepada para mahasiswa tingkat dua yang memilih keahlian pendidikan bahasa Jepang di FPBS UPI tahun akademik 2013/2014.

\section{PUSTAKA RUJUKAN}

Deci, E. L. (1975). Intrinsic Motivation. New York: Plenum Press.

Gardner, R. C.,\& Lambert, W. E. (1959). Motivational Variables In Second Language Acquisition.Canadian Journal of Psychology, 13, pp. 266272. (Reprinted in Gardner, R. C.,\&Lambert, W. E. 1972).

Guo, J.,\& Okita, Y. (2001).Singaporu Kanji Daigakusei No Nihongo Gakushuu 
bahasa \& sastra, Vol. 14, No.2, Oktober 2014

Douki Ni Tsuite [Chinese-

Singaporean University Students'

Motivation To Learn

Japanese].Journal of Japanese

Language Teaching, 110, pp. 130139.

Imuta, T. (2009). Nihongo Kurabu kara

Tsukurareru Kyoushizou: Kyoushi

Shibouno Doukiwa Donoyouni

Arawarerunoka [The Image of

Teachers Made from Japanese

Language Club: How Are Students

Motivated Toward Teachers].Bulletin

of Japanese Language Education, The

Japan Foundation, Bangkok, 6, pp. 165-173.

Japan Foundation. (2013). Indonesia. Survey Report On Japanese-Language Education Abroad 2012,Kurosio Publishers, pp.38-39.

Japan Foundation Japanese-Language Institute, Kansai. (2010). Japanese in Anime \& Manga. Diakses pada 1 Agustus 2014 dari: http://animemanga.jp/

Kamegawa, N. (2006). Nihongo Kyoushi Yousei Katei Gakusei No Shiboudouki Ni KansuruChousakenkyuu: Shakaiteki, Shinriteki Youin Tono Kankei Kara [The Vocational Motives Of The Students Enrolled In Japanese Language Teacher Training Course: Relationship Of Psychological And Social Aspects]. Hyoron Shakaikagaku: Social Science Review, 81, pp. 1-17.

Ministry of Foreign Affairs of Japan. (2013).Pop-Culture

Diplomacy.Diakses pada 1 Agustus 2014 dari : http://www.mofa.go.jp/policy/culture/ exchange/pop/index.

html

Nuibe, Y., Kano, F., \& Ito, K. (1995).
.Daigakusei No Nihongo Gakushuu Dooki Ni Kansuru Kokusai Choosa: Nyuujiirando No Baai [International Survey On University Student Motivation: In Case Of New Zealand]. Journal of Japanese Language Teaching, 86, pp. 162-172.

Onishi, Y. (2010). Ukuraina Ni Okeru Daigakusei No Nihongo Gakushuu Douki [Motivation Among University Students Learning Japanese in Ukraine]. Journal of Japanese Language Teaching, 147, pp. 82-96.

Ryan, R. M.,\&Deci, E. L.(2000). Intrinsic And Extrinsic Motivations: Classic Definitions And New Directions. Contemporary Educational Psychology, 25, pp. 54-67.

.(2002). Overview of

Self-Determination Theory: An Organismic Dialectical Perspective. In E. L. Deci, \&R. M. Ryan (Eds.), Handbook of Self-Determination Research,3-33. Rochester, NY: University of Rochester Press.

Suzuki, Y. (2014). Pop-Culture wo Nihongo Shuutoku e: Manga no Nihongo wo Jiku ni [Japanese For JFL(Japanese as aForeign Language)Learners Through Japanese Pop-Culture: Using Japanese Manga]. Gakuen, 879, pp. 1-14.

Yazaki, M. (2012). Kaigai ni Okeru Anime wo Katsuyoushita Nihongo Gakushuu Katsudou "Anime De Nihongo" no Tenkai: Indonesia no Nenshou Gakushuusha ni Taisuru Doukizuke no Yuukousei [Practice Of "AnimeDe NIHONGO" Japanese Learning Activities With Anime In A Foreign Country: Effectiveness Of Motivation For Japanese Learning Of Young Learners In Indonesia]. Bulletin of the International Center Shizuoka University, 6, pp. 63-77. 